\title{
IL-1/IL-1R Signaling in Head and Neck Cancer
}

\author{
Sven E. Niklander ${ }^{1}$, Craig Murdoch ${ }^{2}$ and Keith D. Hunter ${ }^{2,3 *}$ \\ 1 Unidad de Patología y Medicina Oral, Facultad de Odontologia, Universidad Andres Bello, Viña del Mar, Chile, ${ }^{2}$ Unit of Oral \\ and Maxillofacial Medicine, Pathology and Surgery, School of Clinical Dentistry, University of Sheffield, Sheffield, \\ United Kingdom, ${ }^{3}$ Oral Biology and Pathology, University of Pretoria, Pretoria, South Africa
}

\section{OPEN ACCESS}

Edited by:

Carolina Cavalieri Gomes, Federal University of Minas

Gerais, Brazi

Reviewed by:

Marcelo Lamers,

Federal University of Rio Grande do

Sul, Brazil

Tarcilia A. Silva,

Federal University of Minas

Gerais, Brazil

Daniela-Elena Costea,

University of Bergen, Norway

*Correspondence:

Keith D. Hunter

k.hunter@sheffield.ac.uk

Specialty section:

This article was submitted to

Oral Cancers,

a section of the journal

Frontiers in Oral Health

Received: 09 June 2021 Accepted: 04 August 2021

Published: 26 August 2021

Citation:

Niklander SE, Murdoch C and Hunter KD (2021) IL-1/IL-1R Signaling

in Head and Neck Cancer.

Front. Oral. Health 2:722676.

doi: 10.3389/froh.2021.722676
Decades ago, the study of cancer biology was mainly focused on the tumor itself, paying little attention to the tumor microenvironment (TME). Currently, it is well recognized that the TME plays a vital role in cancer development and progression, with emerging treatment strategies focusing on different components of the TME, including tumoral cells, blood vessels, fibroblasts, senescent cells, inflammatory cells, inflammatory factors, among others. There is a well-accepted relationship between chronic inflammation and cancer development. Interleukin-1 (IL-1), a potent pro-inflammatory cytokine commonly found at tumor sites, is considered one of the most important inflammatory factors in cancer, and has been related with carcinogenesis, tumor growth and metastasis. Increasing evidence has linked development of head and neck squamous cell carcinoma (HNSCC) with chronic inflammation, and particularly, with $\mathrm{IL}-1$ signaling. This review focuses on the most important members of the IL-1 family, with emphasis on how their aberrant expression can promote HNSCC development and metastasis, highlighting possible clinical applications.

Keywords: head and neck cancer, squamous cell carcinoma, oral cancer, tumor microenvironment, IL-1, Anakinra (PubChem CID: 90470007)

\section{INTRODUCTION}

The association between chronic inflammation and cancer has been reported for many years. Fifteen percent of all cancers are attributed to inflammation [1], with a well-recognized association in lung, pancreatic, esophageal, bladder, gastric, cervical, colorectal and prostate cancers [2]. Proinflammatory cytokines present in the tumor microenvironment (TME) can have dual effects; they can stimulate inflammation to decrease tumor progression; or they can stimulate inflammation favoring carcinogenesis, tumor growth and metastasis [3]. Cytokines are produced by host cells in response to factors secreted by the tumor cells or by the tumor itself $[4,5]$. Interleukin-1 (IL-1) is commonly found at tumor sites and is considered one of the most important cytokines of the TME, where it plays a key role in carcinogenesis and tumor progression [6], and its expression has been associated with poor prognosis in cancer patients [7]. There is a growing association linking head and neck squamous cell carcinoma (HNSCC) with chronic inflammation $[8,9]$, in which IL$1 / \mathrm{IL}-1 \mathrm{R}$ signaling seems to be a key player [10]. Cumulating evidence suggests that the effects of IL-1 autocrine and paracrine signaling within the TME is central to HNSCC development. This signaling axis not only leads to increased expression of proteases and factors that dramatically alter the extracellular matrix, aiding tumor cell invasion and metastasis [2, 3], but also increases the production of leukocyte chemoattractants [11]. These molecules selectively recruit both innate and adaptive immune cells to the TME that have both anti- and pro-tumorigenic properties. 
Innate immune cells, such as macrophages and neutrophils, are recruited in large numbers to the HNSCC TME where they secrete tumor promoting and pro-angiogenic factors that exacerbate inflammation, and increase the supply of nutrients and oxygen that drives tumor progression. It is no surprise that high numbers of macrophages and neutrophils in the TME are associated with poor prognosis in HNSCC patients [12, 13]. In contrast, and particularly for HPV-positive HSNCC, increased numbers of $\mathrm{T}$ lymphocytes have been observed and these have been associated with improved prognosis due to direct antitumor cell targeting by these cells [14].

Here, we review the most important members of the IL1 family, with emphasis on how their aberrant expression can promote HNSCC development and metastasis, highlighting possible clinical applications.

\section{IL-1 FAMILY MEMBERS}

The IL-1 family consists of several different ligands and receptors (Table 1) [16]. The most studied ligands are IL- $1 \alpha$ and IL-1 $\beta$, commonly known collectively as IL-1, and the interleukin-1 receptor antagonist (IL-1RA), which antagonizes the effects of IL$1 \alpha$ and IL- $1 \beta$ [17]. These ligands bind to IL- 1 receptor 1 (IL-1R1) and IL-1 receptor 2 (IL-1R2) that are expressed by several cells. IL-1R1 is a biologically active receptor with the ability to bind to either form of IL-1 [18], while IL-1R2 is non-biologically active and acts as a decoy receptor, inhibiting the effects of IL-1 [19,20].

\section{IL-1 $\alpha$}

IL- $1 \alpha$ is produced initially as a $31-33 \mathrm{kDa}$ precursor protein (preIL-1 $\alpha$ ) that is cleaved into its $17 \mathrm{kDa}$ mature C-terminal component (mIL-1 $\alpha$ ) and a $16 \mathrm{kDa} \mathrm{N}$-terminal propiece (ppIL$1 \alpha)$ by the calcium-activated cysteine protease, calpain $[5,21-$ 23]. All forms of IL- $1 \alpha$ are biologically active [24]. PreIL-1 $\alpha$ lacks a leader peptide and therefore cannot be secreted and remains intracellular $[17,25]$. Despite not being secreted, preIL$1 \alpha$ can localize on the cell surface of macrophages, endothelial cells, fibroblasts and dendritic cells [26] where is referred to as membrane-bound IL- $1 \alpha$. Here it acts in a juxtracrine manner by activating the IL-1R1 receptor of surrounding cells [17]. Both preIL- $1 \alpha$ and mIL- $1 \alpha$ are expressed constitutively in epithelial

TABLE 1 | IL-1 family of ligands and receptors (adapted from Dinarello, [15]).

\begin{tabular}{lll}
\hline IL-1 family member & Receptor & Function \\
\hline $\mathrm{IL}-1 \alpha$ & $\mathrm{IL}-1 \mathrm{R} 1 / \mathrm{IL}-1 \mathrm{R} 2$ & $\mathrm{Pl} / \mathrm{Al}$ \\
$\mathrm{IL}-1 \beta$ & $\mathrm{IL}-1 \mathrm{R} 1 / \mathrm{LL}-1 \mathrm{R} 2$ & $\mathrm{Pl} / \mathrm{Al}$ \\
$\mathrm{IL}-1 \mathrm{RA}$ & $\mathrm{IL} 1-\mathrm{R} 1$ & $\mathrm{Al}$ \\
$\mathrm{IL}-18$ & $\mathrm{IL}-1 \mathrm{R} 5$ & $\mathrm{PI}$ \\
$\mathrm{IL}-33$ & $\mathrm{IL}-1 \mathrm{R} 4$ & $\mathrm{PI}$ \\
$\mathrm{IL}-36 \alpha, \beta, \gamma$ & $\mathrm{IL}-1 \mathrm{R} 6$ & $\mathrm{Pl}$ \\
$\mathrm{IL}-36 \mathrm{RA}$ & $\mathrm{IL}-1 \mathrm{R} 6$ & $\mathrm{Al}$ \\
$\mathrm{IL}-37$ & $\mathrm{IL}-1 \mathrm{R} 5$ & $\mathrm{Al}$ \\
$\mathrm{IL}-38$ & $\mathrm{IL}-1 \mathrm{R} 6$ & $\mathrm{Al}$
\end{tabular}

and endothelial cells and are considered to act in an autocrine or paracrine manner [27-29]. IL-1 $\alpha$ plays an important role in inflammation acting in a juxtracrine manner [17] and has been related with several other cellular functions, such as onset of senescence [30-32], cell growth, cell differentiation [28, 33], immune response [34] and regulation of gene expression [35-37].

To exert its biological function, mIL- $1 \alpha$ binds to IL-1R1 to trigger different cellular functions, but preIL- $1 \alpha$ and ppIL- $1 \alpha$ can also interact directly with the DNA without binding to IL-1R1 in a variety of cells $[28,38]$. This is because ppIL- $1 \alpha$ contains a canonical nuclear localization sequence (NLS) that enables it to interact directly within the nucleus in a non-IL$1 \mathrm{R} 1$-dependent manner $[39,40]$. PreIL- $1 \alpha$, via ppIL- $1 \alpha$, interacts with histone acetyltransferases Gcn5, p300, PCAF and with the adaptor component Ada3, inducing protein transcription without activating IL-1R1 [41], and in doing so exerts different intracellular functions, such as NF- $\kappa \mathrm{B}$ and AP-1 activation [38], modulation of endothelial proliferation [28], migration [42] and cytokine production [43].

\section{IL-1 $\beta$}

IL- $1 \beta$ is the classic inflammatory secreted cytokine produced in response to inflammatory signals and other stimuli and can act in a paracrine or systemic manner $[44,45]$. IL-1 $\beta$ is mainly produced by monocytes by intracellular cleavage from its $31 \mathrm{kDa}$ precursor protein (pIL-1 $\beta$ ) into a $17.5 \mathrm{kDa}$ mature form (mIL$1 \beta$ ) by caspase- 1 or IL- $1 \beta$ converting enzyme (ICE) $[5,46]$. The precursor form of IL-1 $\beta$ is considered to be an inactive immature form of the protein [18]. Unlike preIL- $1 \alpha$, pIL- $1 \beta$ is not expressed in health [47]. Many microbial products are able to stimulate IL$1 \beta$ secretion, and when produced, IL- $1 \beta$, together with IL- $1 \alpha$, has the ability to upregulate its own gene expression in vitro and in vivo [48]. IL-1 $\beta$ expression is mainly restricted to inflammatory cells, where it is regulated in response to external stimuli [49]. IL$1 \beta$ is $25-50$-fold more abundant than IL- $1 \alpha$ in stimulated human peripheral mononuclear cells [50], and upon activation, around $70 \%$ of IL- $1 \beta$ is secreted by these cells after $24 \mathrm{~h}$ stimulation [51].

The main functions of IL- $1 \beta$ are to induce upregulation of cytokines, chemokines, adhesion molecules, acute phase proteins and tissue remodeling enzymes [17, 49, 52]; it may also act as an angiogenic factor in tumors [53], inducing the production of vascular endothelial growth factor (VEGF) via cyclooxygenase (COX)-2 activation [54]. IL-1 $\beta$ has been associated with the pathobiology of many diseases, such as familial periodic fever syndromes [55], multiple organ failure in sepsis [56], rheumatoid arthritis, type II diabetes [57], chronic obstructive pulmonary disease [58] and growth, vascularization and metastasis of malignant tumors [53].

\section{IL-1 Receptors IL-1R1}

IL-1R1 is the main receptor through which IL-1 exerts its effects and is found on $\mathrm{T}$ cells, keratinocytes, fibroblasts, synovial cells, endothelial cells, chondrocytes, and hepatocytes $[17,51]$. All active forms of IL-1 (pIL- $1 \alpha$, mIL- $1 \alpha$ and mature IL-1 $\beta$ ) bind with similar affinity to IL-1R1, triggering biological actions $[49,59]$. IL-1R1 is an $80 \mathrm{kDa}$ molecular weight protein and 
belongs to the immunoglobulin (Ig) super family. It has a single transmembrane portion with a cytosolic region and an extracellular segment that contains three domains homologous to Igs, with seven $\mathrm{N}$-linked glycosylation sites. To be active, the IL1R1/IL-1 extracellular complex requires the additional binding of a co-receptor, the IL-1 receptor accessory protein (IL-1RAcP) or IL-1R3, forming a trimeric complex $[60,61]$. IL-1RAcP is essential for signal transduction, as murine fibroblasts deficient in IL-1RAcP showed no response after IL-1 stimulation [62]. After IL-1 binds to the extracellular domain, the Toll/interleukin1 receptor (TIR) domain of the cytoplasmic portion of IL-1R1 triggers a cascade of intracellular signaling events that result in the phosphorylation and degradation of inhibitor nuclear

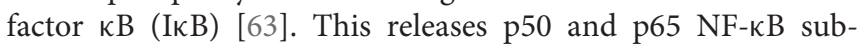
units that upon phosphorylation are transported into the nucleus and bind to specific DNA promotor sequences, initiating gene transcription $[49,64]$. Although it is generally accepted that IL$1 \mathrm{R} 1$ is localized on the cell membrane, recent reports have shown that the receptor is also present on the nuclear membrane of malignant oral keratinocytes $[65,66]$, although the relevance of this nuclear localization is unknown.

\section{IL-1R2}

IL-1R2 is an inactive IL-1 receptor that acts as a molecular trap, capturing IL-1 on the plasma membrane or within the extracellular space when membrane IL-1R2 is cleaved and present as a soluble receptor, without triggering agonist activity [61, 67]. Together with IL-1RA, these IL-1R2 forms act as IL-1 inhibitors [68]. IL-1R2 is also a member of the Ig super family, consisting of three Ig-like domains in the extracellular portion and a transmembrane segment. It is found on $\mathrm{B}$ and $\mathrm{T}$ helper 2 cells, neutrophils, monocytes, bone marrow and microglial cells [15]. The main difference between the two IL-1R forms is that, unlike Il-1R1, IL-1R2 has no TIR domain, and is therefore unable to trigger intracellular signaling, rendering it biologically inactive [69].

\section{IL-1RA}

IL-1RA blocks the binding of IL- $1 \alpha$ and IL- $1 \beta$ to IL-1R1, having no cross-reactivity with IL- $1 \alpha$ and IL- $1 \beta$ [70]. When binding to IL-1R1, IL-1RA does not recruit IL-1RAcP. Thus, IL-1RA has no agonist action, acting as a pure antagonist molecule [71]. IL-1RA mainly binds IL-1R1, having little effect on IL-1R2, which is in agreement with their action as IL-1 inhibitor molecules [72]. As IL-1RA competes with IL-1 for the same receptor, it is found in higher concentrations than IL-1. For example, in the skin, IL-1RA expression has been found to be $\approx 100$-fold higher than IL- $1 \alpha$ [27]. Similarly, a study with recombinant IL-1RA showed that in order to have $50 \%$ inhibition of IL-1-induced actions, IL-1RA had to be present in 5-100-fold excess over both IL- $1 \alpha$ and IL-1 $\beta$ [73]. This is because IL-1R1 is very sensitive to small amounts of IL-1. Even 5\% IL-1 receptor occupancy is able to trigger a complete biological response [63]. So, for IL-1RA to efficiently block the effects of IL-1, it must be in abundance [15].

Two main forms of IL-1RA are now recognized; a secreted form (sIL-1RA) [74] and an intracellular form (icIL-1RA) [75]. Intracellular IL-1RA has the same amino acid structure as the secreted form, but lacks a leader peptide that prevents its secretion. The intracellular variant is transcribed by alternate splicing of the same gene as sIL-1RA [75]. Three isoforms of the intracellular form have been reported (icIL-1RA1 or transcript variant 3, icIL-1RA2 or transcript variant 2 and icIL1RA3 or transcript variant 4) [76-78], with icIL-1RA1 being the most studied. Both secreted and intracellular IL-1RA forms are tissue specific. icIL-1RA is constitutively expressed in tissue sites exposed to environmental factors, such as epithelial cells of the skin, oral cavity, vagina, ovaries and upper respiratory tract $[65,75,79,80]$, while sIL-1RA is found in monocytes, neutrophils and other cells [77].

\section{Other IL-1 Family Members}

The IL-1 family of proteins comprises of several other members in addition to IL-1 (Table 1). IL-18, whose actions are mediated by binding to IL-1R5, is considered an immunomodulatory cytokine important for IFN $\gamma$ production and is up-regulated by keratinocytes in response to contact sensitizers [81, 82]. IL-33 is a pro-inflammatory cytokine that binds to IL-1R4, but similarly to IL- $1 \alpha$, can also exert its actions directly to the nucleus [83]. IL36 is an inflammatory protein associated with the development of psoriasis and acts by binding to IL-1R6. Decreased levels of its specific antagonist, IL-36RA, have also been related with the development of pustular psoriasis [84]. Similar to IL-18, IL-37 also binds to and activates IL-1R5. However, unlike IL18 , IL-37 is considered an anti-inflammatory cytokine, where low levels are thought to contribute to disease severity [61]. IL38 also has predominantly anti-inflammatory actions that are mediated by binding to IL-1R6 [85] where it has been shown to reduce clinical manifestations of systemic lupus erythematosus and arthritis [86].

\section{IL-1 IN KERATINOCYTE BIOLOGY}

IL- $1 \alpha$ and IL-1RA are constitutively expressed by skin and oral keratinocytes $[34,65,80,87]$. IL- $1 \beta$ can be found intracellularly [87], but because keratinocytes lack ICE, pIL-1 $\beta$ cannot be cleaved into its $18 \mathrm{kDa}$ mature form and remains inactive and is not reported to be secreted $[87,88]$. However, it has been recently reported that normal oral keratinocytes do secrete IL$1 \beta$ (although in very low levels) that significantly increases with cell aging, although the underlying mechanism is unknown and might be related with the culture conditions (co-culture with irradiated fibroblasts) [65]. To counteract the action of IL-1, keratinocytes mainly express icIL1-RA1 [79, 89], which is localized both in the cytoplasm and inside the nucleus [65], whereas the secreted isoform (sIL-1RA) is either absent or found in very low levels $[65,90]$. This makes biological sense as keratinocytes mainly express IL- $1 \alpha$, which is considered an intracellular cytokine, thus an intracellular antagonist is needed to regulate its activity. Although the main actions of icIL1RA are attributed to its ability to block IL-1R1, icIL1-RA1 is also able to decrease IL- 6 and CXCL8 levels by inhibition of the p38 MAPK and NF- $\mathrm{B}$ signaling pathways in an IL-1R1independent manner $[89,91]$. Thus, it is likely that the main icIL-1RA1 functions are related to the regulation of intranuclear 
IL-1 $\alpha$. Keratinocytes also express IL-1R2 at higher levels than IL1R1 (resting and when activated). So, both IL-1R2 and icIL-1RA have synergistic roles in regulating IL-1 action on keratinocytes, protecting these cells from excessive autocrine activation of IL$1 \alpha[92]$.

IL- $1 \alpha$ and icIL-1RA may have an important role in keratinocyte growth, differentiation, and aging. An in vitro study testing the growth conditions for different epithelial cells found that IL-1 $\alpha$ inhibited the proliferation of stratified squamous epithelial cells, whereas IL-1RA enhanced it. Moreover, significant growth promotion in normal epidermal keratinocytes was observed upon addition of exogenous IL-1RA [93]. Changes in the ratio of icIL-1RA:IL- $1 \alpha$ might help to control growth and differentiation of human skin, as icIL-1RA accumulates in more differentiated cells and IL-1RA expression in oral keratinocytes is positively correlated with the expression of involucrin (a marker of cell terminal differentiation that is restricted to the granular cell layer) [94], whereas IL- $1 \alpha$ is uniformly expressed in all keratinocyte maturation stages [33]. icIL-1RA1 is reported to be an important factor in the regulation of oral keratinocyte senescence and the development of the senescence-associated secretory phenotype (SASP) [65]. Cellular senescence corresponds to a cellular state characterized by permanent cell growth arrest in response to different stressors in order to avoid propagation of genetically damaged cells [95]. When cells senesce, they remain metabolically active a develop a SASP characterized by the presence of multiple pro-inflammatory factors which have been related with the development of age-related disorders, including cancer [96]. Oral keratinocytes lacking icIL-1RA1 have been shown to senesce prematurely when compared with keratinocytes expressing icIL1RA1, and icIL-RA1 was found to regulate the expression of two important SASP factors, IL-6 and CXCL8 [65], which have been associated with the development of malignancies [96].

\section{IL-1 SIGNALING IN HEAD AND NECK SQUAMOUS CELL CARCINOMA}

IL- $1 \alpha$, IL-1 $\beta$, and IL-1R1 have been reported to be constitutively expressed in HNSCC [66, 97-99] whilst decreased IL-1RA expression has been observed early in the oral carcinogenesis process [65]. As different members of the IL-1 signaling pathway have reported to have important functions in HNSCC carcinogenesis and tumor progression, we will review them separately.

\section{IL-1 $\alpha$}

IL- $1 \alpha$ expression in HNSCC contributes to cell growth and survival and has been considered by some authors as a prognostic factor. In the study of Leon et al. [100], patients with metastatic HNSCC displayed higher expression of IL- $1 \alpha$ than patients without metastases. Constitutive IL- $1 \alpha$ over-expression was correlated with that of IL- 1 family genes, such as IL- $1 \beta$ and IL-1RA. IL- $1 \alpha$ expression also correlated with increased cell transmigration of tumor cells across the endothelium, which was inhibited by addition of IL-1RA. IL-1 $\alpha$ expression also correlated with different genes that have been associated with metastasis, particularly MMP-9 (a matrix metalloproteinase associated with EMT), $\mathrm{PGE}_{2}$ (a product of COX-2 activation associated with metastases of OSCC), VEGF (the most important angiogenic factor in HNSCC) and CXCL8 [100]. The five-year distant metastasis-free survival was $70 \%$ for patients with high tumor levels of IL- $1 \alpha$ in contrast to $95 \%$ for patients with low expression

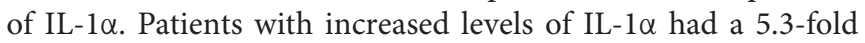
higher risk of developing metastasis and patients with distant metastases had also a significant increase in secreted IL-1 $\alpha$ [100].

IL- $1 \alpha$ has also been reported to induce the overexpression of IL-6 [97] and CXCL8 in HNSCC cell lines, the latter by inducing NF- $\kappa$ B and AP-1 pathways [36]. This is of importance as IL-6 and CXCL8 are considered important "oncogenic cytokines", as they are able to cause EMT [101], stimulate angiogenesis and tumor growth [102, 103], disrupt cell-cell communication, impede macrophage function and promote epithelial and endothelial cell migration and invasion [104]. NF- $\mathrm{B}$ is considered a key factor in the regulation of the inflammatory infiltrate observed in the TME [105] and has been associated with the acquisition of a malignant phenotype of HNSCC, as is associated with tumor angiogenesis [106], EMT [107], invasion [108, 109] and metastasis [110]. In addition, inactivation of NF- $\mathrm{B}$ in HNSCC suppressed cell survival and expression of IL-1 $\alpha$, IL-6, CXCL8 and GM-CSF in a murine model of head and neck cancer [111] and its aberrant expression is associated with poor prognosis in solid cancers [112]. AP-1 expression increases with HNSCC progression and induces bcl-2 expression that is associated with suppression of apoptosis and resistance to chemoradiation therapy [113] (Figure 3).

\section{IL-1 $\beta$}

The mechanism by which IL- $1 \beta$ is constitutively overexpressed in HNSCC is not clear, but a single nucleotide polymorphism of the IL- $1 \beta$ gene could explain this. In fact, IL-1 $\beta-511$ polymorphism has been reported to be a significant risk factor for the development of OSCC [114]. IL-1 $\beta$ is identified as a key node gene in the tumor microenvironment (TME) of OSCC in vivo [115]. Keratinocytes lack ICE and therefore should not be able to produce the mature active form of IL$1 \beta$. However, other proteases are able to cleave IL- $1 \beta$ precursor form, suggesting that pIL-1 $\beta$ can be processed after secretion by other proteases that are present in the TME [116]. In agreement with this, IL- $1 \beta$ produced by oral keratinocytes and HNSCC cells is biologically active. Interaction of IL- $1 \beta$ with the TME leads to monocyte recruitment that then differentiate into tumor-associated macrophages (TAMs) whose increased levels in HNSCC are associated with poor prognosis [12, 117]. Also, stimulates the production of numerous cytokines by different cell types, such [116] as cancer-associated fibroblasts (CAFs), normal fibroblast, endothelial cells, neutrophils as well as oral dysplastic and cancer cells, among others [10, 11, 98, 118], through an IL-1-dependent innate immune response.

The IL- $1 \beta$ found in the TME is also produced by other cells in addition to HNSCC cells. A recent report demonstrated that IL- $1 \beta$ produced by CAFs induces CCL 22 mRNA overexpression in oral cancer cells. CCL22 is implicated in the recruitment of 
A

prelL-1a<smiles>C1CCCCC1</smiles>

31-33 kDA

Active

C

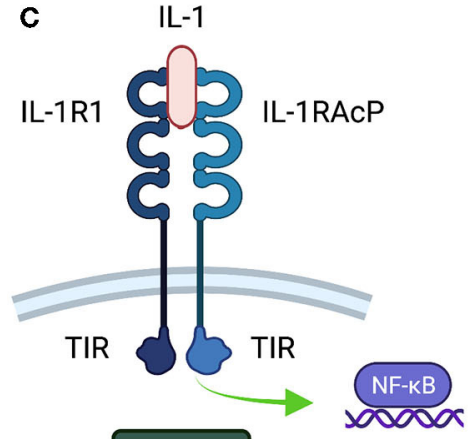

Signal

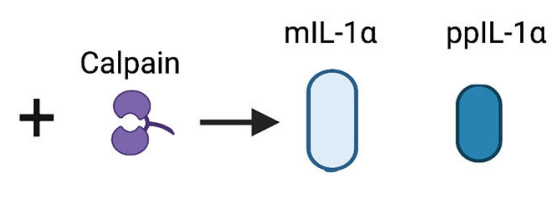

17 kDA 16 kDA

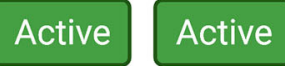

D

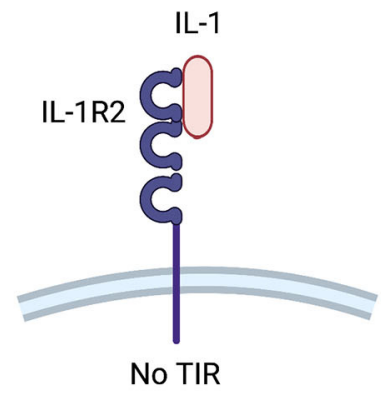

No signal
B

pIL-1 $\beta$

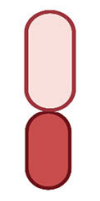

$31 \mathrm{kDA}$

Inactive

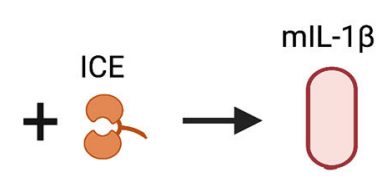

$17.5 \mathrm{kDA}$

Active
E

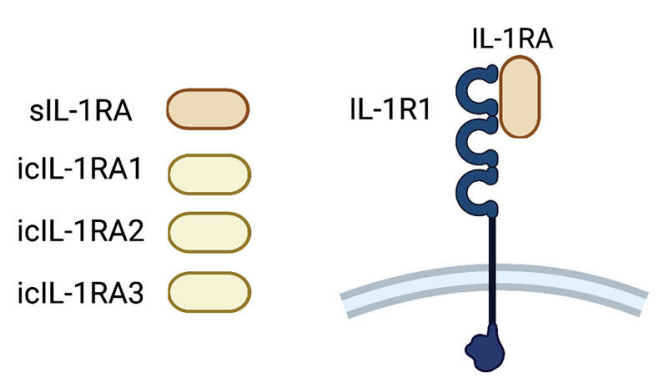

No signal

FIGURE 1 | (A) IL-1 $\alpha$ and (B) IL-1 $\beta$ forms. (C) IL-1R1 agonist receptor. To be active, IL-1R1 needs the binding of IL-1RAcP. Both IL-1R1 and IL-1RAcP have a TIR domain, which after a series of phosphorylation following IL-1 binding, activate NF-kB. (D) IL-1R2 decoy receptor binds to IL-1 without triggering any agonist action as lacks of a TIR domain. (E) IL-1RA variants bind to IL-1R1, blocking the binding of IL-1 without recruiting IL-1RAcP, thus triggers no agonist action. This image was created with Biorender.

$\mathrm{T}$ regulatory cells, and its expression in oral cancer patients has been associated with a reduced disease-free survival [119]. Tumor-associated macrophages (TAMs) also secrete IL-1 $\beta$, which, together with the actions of TNF- $\alpha$ stimulate tumor angiogenesis by inducing the release of VEGF and CXCL8 by HNSCC cells [120]. This creates an inflammatory TME that can predispose to tumor progression [121] (Figure 1). For example, in HNSCC IL-1 signaling drives neutrophil and monocyte recruitment [10], and accumulation of these tumorassociated leukocytes has been associated with poor prognosis $[13,122]$. The IL-1/IL-1R axis mediates chemokine release from normal tonsillar fibroblasts (NTF) induced by HPV-negative oropharyngeal carcinoma (OPC) cells, which can be reverted with IL-1 inhibition [11]. This is of significance, as for example, CXCL1 and MMP-1 produced by CAFs in response to IL- $1 \beta$ from OSCC cells, increased the invasion and migration capabilities of OSCC cells [123]. Also, IL-1 released from HNSCC cells has been shown to stimulate COX-2 production by CAFs [124] that correlated with lymphangiogenesis [125] and E-cadherin regulation, important factors for epithelial-to-mesenchymal transition (EMT) development [126], and increased risk of distant metastases [127]. In OSCC, IL-1 $\beta$ produced by tumor cells can act in a paracrine manner, inducing the expression of fascine that is associated with ECM degradation and tumor cell invasion [128] (Figure 2).

The oncogenic properties of IL-1 $\beta$ have also been demonstrated using in vivo models. In a mouse oral cancer model in which carcinogenesis was induced by mimicking tobacco and areca nut carcinogens, an increase in pIL-1 $\beta$ mRNA positively correlated with the presence of malignant change (from normal, to mild, through severe dysplasia to OSCC). In agreement with these findings, OSCC and dysplastic cell lines from smokers and/or betel quid chewers had higher IL- $1 \beta$ levels than controls, with inflammasome components constitutively expressed in OSCC cells that allows the cleavage of pIL-1 $\beta$ into mIL-1 $\beta$. IL-1 $\beta$ might have an important role in the induction of EMT in OSCC, as in the same study, OSCC cells treated with IL-1 $\beta$ showed upregulation of Snail and Slug (two repressors of E-cadherin expression), increased vimentin expression, and downregulation of E-cadherin. This was also correlated with a change in cell morphology, from a squamous cell-like shape, in cells not exposed to IL-1 $\beta$, to a spindle-like shape in OSCC cells exposed to IL-1 $\beta$. The migration capacity of OSCC treated with IL-1 $\beta$ increased significantly after 48 hours, compared to untreated OSCC. These findings strongly suggest a role of IL-1 $\beta$ in EMT in OSCC [98], which has also been reported by 


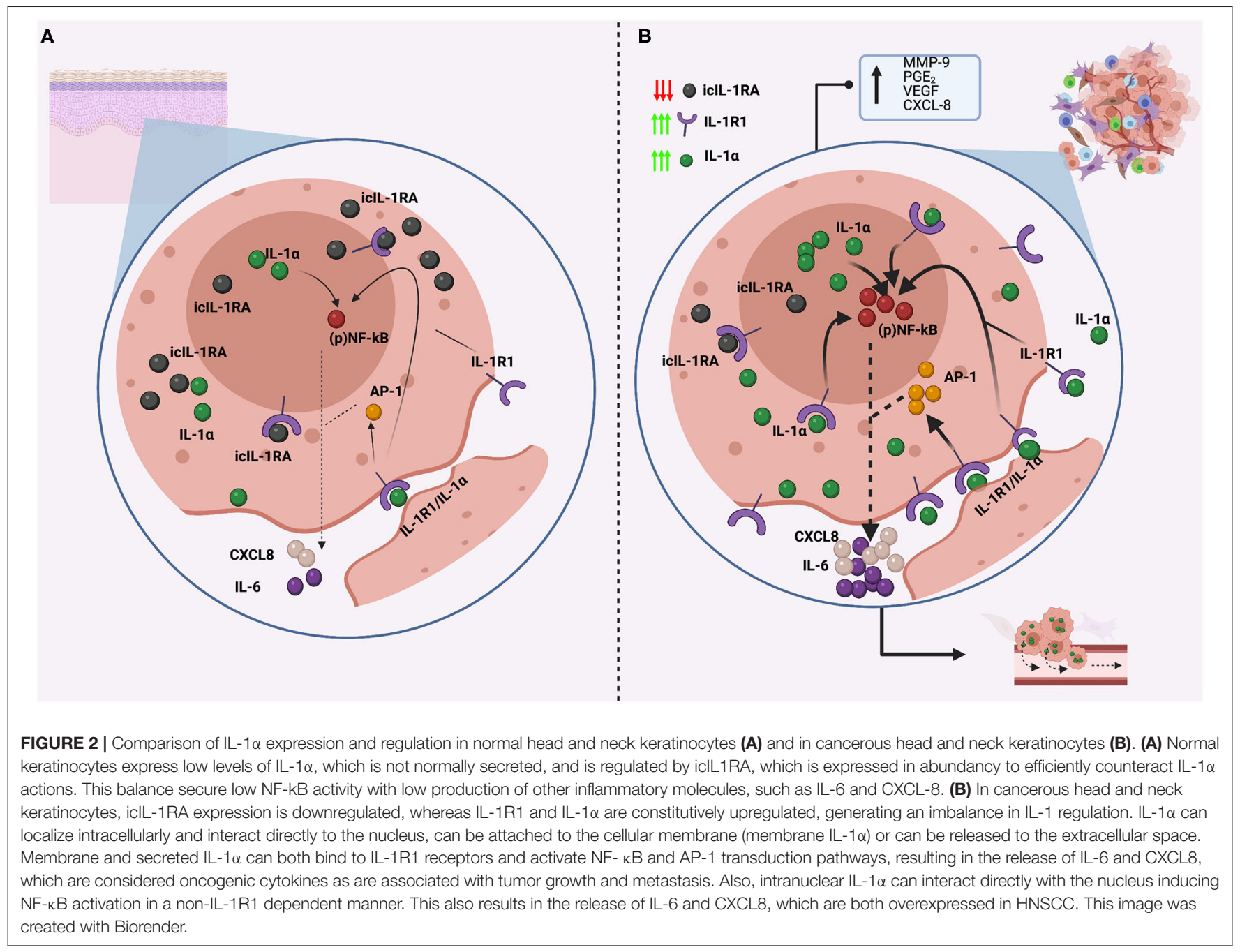

others $[126,129,130]$. This is also supported by the fact that IL-1 $\beta$ silencing reduces OSCC tumor size in vivo [115] and that elevated IL-1 $\beta$ expression has been related with lymph node metastasis of OSCC [131].

\section{IL-1RA}

Several gene expression profiles of HNSCC have shown that $I L-1 R N$ is downregulated in HNSCC when compared to matched normal oral mucosa [132-139]. In addition, IL$1 R N$ was reported to be a reliable marker when predicting the presence or absence of HNSCC in tissue samples in a cohort of 46 patients with HNSCC, with sensitivity and specificity of 93.5 and 95.7\%, respectively [138]. Despite this, very little is known about the role of IL-1RA in HNSCC.

Von Biberstein et al. [99] reported an imbalance in the IL1:IL-1RA ratio in HNSCC when compared to healthy patients, that was attributed mainly to an increase in the levels of IL$1 \alpha$ and IL- $\beta$, but also to a decrease in the levels of IL-1RA. These authors also reported higher expression of IL-1RA in the more differentiated epithelial cells within the tumors. IL1RA protein expression decreases progressively during oral carcinogenesis and in HNSCC [65], which is in agreement with a previous report [80] and IL-1R2, the other IL-1 inhibitor, is not able to compensate for IL-1RA lack of expression [65]. Also, IL-1RA levels decrease significantly in immortal normal and dysplastic oral keratinocytes when compared to their mortal counterparts. This suggest that IL-1RA downregulation during the carcinogenic process might be an important step for the acquisition of a malignant phenotype, primarily because the binding of IL-1 to IL-1R1 is not inhibited, allowing dysregulated activation of the IL-1/IL-1R1 axis that can predispose to the carcinogesis process in different ways (Figures 1, 2). Moreover, In oral keratinocytes, icIL-1RA1 regulates IL-6 and CXCL8 secretion, most likely by interfering with NF- $\kappa$ B activation [65]. Both IL- 6 and CXCL- 8 secretion is canonically regulated by $\mathrm{NF}-\kappa \mathrm{B}$, and icIL-1RA1 is able to regulate NF- $\kappa \mathrm{B}$ activation wheter by inhibiting IL-1 binding to IL-1R1, or by directly interfering with the NF-kB signaling pathway (see below). Thus, a downregulation of IL-1RA would allow overexpression of these cytokines (Figure 3).

There has been much debate about the specific functions of icIL-1RA. icIL-1RA is able to bind to IL-1R1, but as a stricktly intracellular molecule, it is more likely that the 


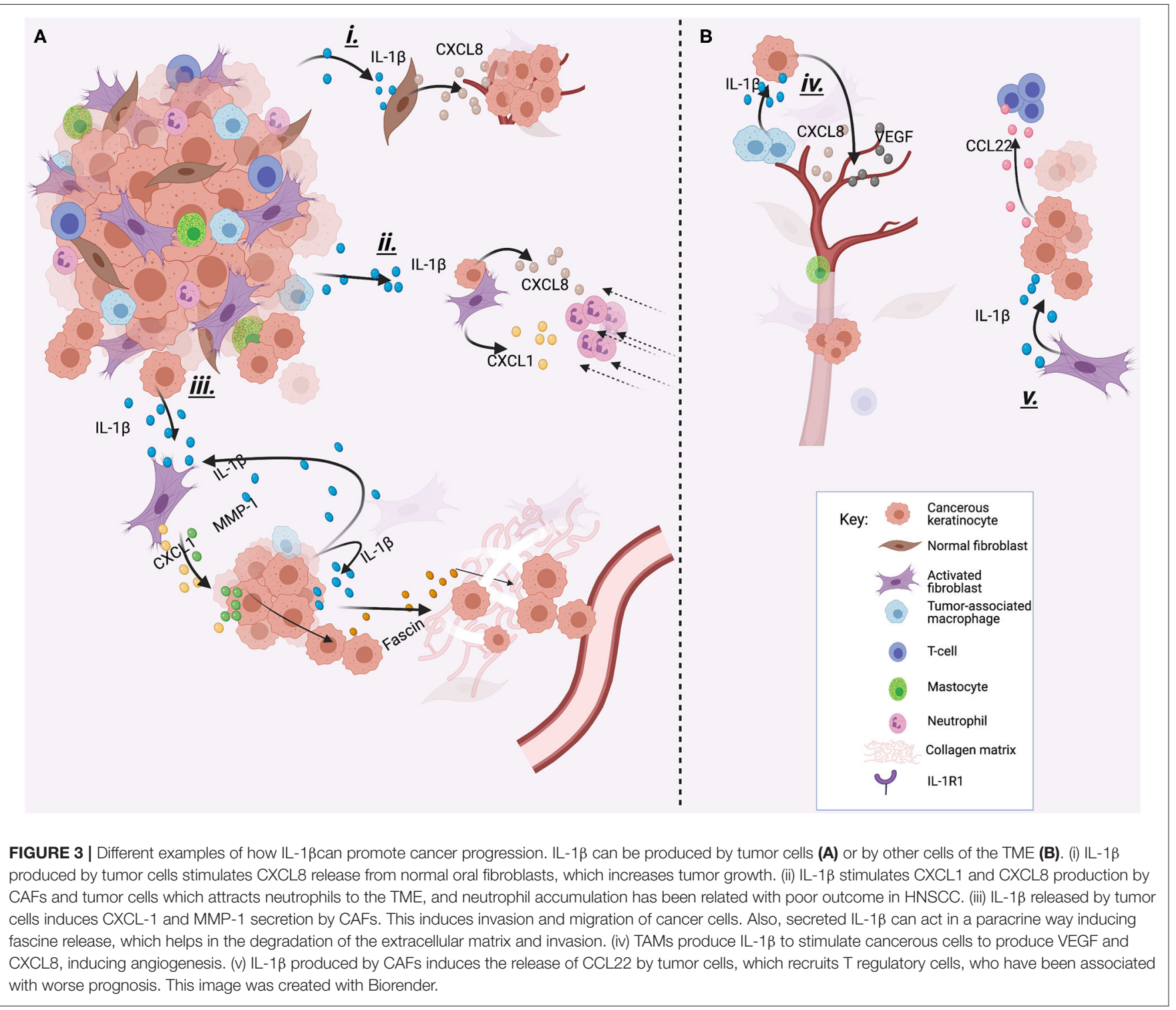

main functions of icIL-1RA are not related to IL-1R1 binding. IL-1R1 is located on the membrane surface, thus, icIL-1RA would require secretion into the extracellular space for it to block IL-1R1, although IL-1R1 intranuclear localization in oral dysplastic and cancer cells has been recently described [65]. It has been proposed that the main function of icIL-1RA is to counteract the intranuclear action of IL- $1 \alpha$. icIL-1RA may act intracellularly by binding to other cytoplasmic proteins in order to interfere with the downstream cascade. In fact, icIL-1RA has been reported to interact with the third component of the COP9 signalosome (CSN3) inhibiting CSN-associated kinases [91]. The signalosome (CSN) is found in the cytoplasm and nucleus of all mammalian cells, and among other functions, it has kinase activity that induce phosphorylation of proteins involved in signal transduction. When interacting with CSN3, icIL-1RA1 inhibits phosphorylation of $\mathrm{p} 53$, c-Jun and IкB thereby inhibiting IL- $1 \alpha$-mediated IL- 6 and CXCL8 transcription. These inhibitory actions may also affect the p38 MAPK signal transduction pathway, as transfected keratinocytes with icIL-1RA1 showed no detectable phosphorylated p38 MAPK when stimulated with IL$1 \alpha$ [91]. Similar icIL-1RA1 inhibitory mechanisms have also been reported in intestinal epithelial cells [89]. Böcker et al. [140] also reported inhibition of IL-1-induced CXCL8 expression by icIL-1RA1, but did not specify the mechanism underlying this inhibition. It has been proposed that the role of CSN3 is to bring icIL-1RA1 close to a kinase in order to inhibit its action. So, icIL-1RA1 would block an upstream kinase in the p38 MAPK or NF- $\mathrm{B}$ pathways, indirectly inhibiting p38 MAPK or NF$\kappa \mathrm{B}$ phosphorylation and consequently, its downstream products, such as IL-6 and CXCL8 [91].

It can be hypothesized then, that downregulation of icIL1RA in HNSCC could lead to de-regulated expression of pro-inflammatory cytokines related to cancer development by allowing the un-controlled activation of IL-1 $\alpha$ and 
NF-кB (Figure 3). This speculation is based on the finding that OSCC constitutively express higher levels of IL- $1 \alpha$ and NF$\kappa \mathrm{B}$ than healthy controls $[8,100,118,141]$ and that levels of IL-6 and CXCL8 are elevated in OSCC $[142,143]$. In addition, IL- $1 \alpha$ can interact directly with nuclear DNA an induce malignant transformation [40]. Thus, if endogenous levels of IL- $1 \alpha$ are constitutively overexpressed, and its mains inhibitor (icIL-1RA) is downregulated, there could be more chances for icIL-1 $\alpha$ to induce malignant transformation. In agreement with this hypothesis, a recent study comparing nuclear and cytoplasmic IL- $1 \alpha$ expression in OSCC showed that the high expression of nuclear IL- $1 \alpha$ in combination with EGFR, was associated with perineural invasion and high risk of recurrence and worse progression-free survival, compared to OSCC expressing none or moderate nuclear IL-1 $\alpha$ in combination with EGFR [144]. These studies suggests that uncontrolled nuclear IL- $1 \alpha$ activity might be of clinical importance.

There is some controversy about the role of IL-1RA in HNSCC. Shiiba et al. [80] reported an increase of IL-1RA (T3/T4) compared to early OSCC cases (T1/T2), suggesting that IL-1RA expression could increase tumor progression. Similar observations have been reported by other authors in gastric [145] and cervical carcinomas [146], reporting a more aggressive behavior from IL-1RA expressing tumors. A possible explanation to this could be that over time, endogenous IL-1 antagonism (which is likely to be beneficial in antagonizing disease progression) changes the tumor phenotype to one that is less susceptible to IL-1 inhibition. Thus, the disease progresses, and IL-1RA levels remain high [71]. Also, most of the aforementioned studies measured sIL-1RA, so the increase in sIL-1RA may be due to a decrease in icIL-1RA levels. Nevertheless, these contradictory functions of IL-1RA in different cancers only highlights the multiple functions that IL-1RA displays in relation to the specific tissue, cell type or the microenvironment in which it is present.

\section{IL-1R1}

A number of different polymorphisms of the ILIR1 gene have been related with a reduced (rs956730) or increased (rs3917225) risk for developing HNSCC [147]. IL-1R1 is overexpressed by oral dysplastic and OSCC cells compared to normal oral keratinocytes [65], which seems to provide phenotypic advantages. IL-1R1 promotes oral cancer growth and metastasis by upregulating CXCR4 (a chemokine receptor involved in tumor progression, angiogenesis and metastasis) after IL-1 $\beta$ stimulation, and IL-1R1 inhibition with recombinant IL-1RA has shown to reverse these effects [66]. IL-1R1 is also constitutively expressed by normal oral fibroblasts [11]. This is of importance as HNSCC cells are able to secrete IL- $1 \beta$ which stimulates other cells of the TME (such as fibroblasts) to generate chemokines and other inflammatory molecules creating an inflammatory TME with cancer promoting properties [11].

\section{TRANSLATIONAL POTENTIAL}

\section{Utility as a Saliva Biomarker}

The discovery that saliva contains molecules that are able to translate the presence or activity of local or systemic diseases has opened a new diagnostic field known as salivary diagnostics
[148]. The use of saliva as a diagnostic method is very practical, as saliva can be collected in an easy, non-invasive way. As there is evidence suggesting that IL- $1 \alpha, \mathrm{IL}-1 \beta$, and IL-1RA are involved in the pathogenesis of HNSCC and can be detected in the saliva of cancer patients [149-151], different studies have explored their possible use as diagnostic or prognostic biomarkers for this cancer.

IL- $1 \beta$ is overexpressed in the saliva of oral cancer patients compared to oral leukoplakia and control patients [152, 153] and IL-1 $\beta$ salivary levels have been shown to discriminate between OSCC subjects and controls [154-156], but not between oral potentially malignant disorder (OPMD) patients and healthy subjects [155]. The reported AUC of salivary IL-1 $\beta$ to differentiate between OSCC and control individuals varies between 0.729 and $0.7724[154,155]$ but increases to 0.901 when considering only late stage OSCC [155]. Also, the discriminatory power of salivary IL-1 $\beta$ increases when used with other markers, such as CXCL8, SAT1 and DUSP1 [156]. In the study by Singh et al. salivary IL-1 $\beta$ failed to distinguish between posttreatment OSCC individuals and healthy subjects, suggesting a normalization of IL-1 $\beta$ salivary levels after tumor removal [155]. In agreement, a study in which the authors analyzed the expression of 50 cytokines (including IL- $1 \beta$, IL- $1 \alpha$, and IL-1RA) in the saliva of 16 OSCC patients before and after surgical intervention, showed a significant decrease in salivary IL-1 $\beta$ levels after tumor resection. No significant changes in other cytokine levels were reported [150]. Similar results were also reported elsewhere [157]. IL-1 $\alpha$ expression is also reported to be increased in the saliva of tongue SCC (TSCC) patients compared to controls and has also been associated with tumor growth pattern $[9,158]$. Patients presenting with endophytic TSCC exhibited significantly higher IL- $1 \alpha$ levels compared to exophytic TSCC, which correlated with a decreased survival rate in the group of endophytic tumors [158].

IL-1RA can also be detected in the saliva and its expression is reported to be significantly decreased in the saliva of OPMD and OSCC patients compared to healthy controls [151]. Opposite to salivary IL-1RA, plasma circulating IL-1RA levels have been shown to be increased and OSCC patients and correlated with tumor size, but were not related with different outcome measures [159]. By itself, salivary IL-1RA displayed a poor performance in diagnosing OSCC, but in combination with other proteins (SLC3A2 and S100A2), it was able to distinguish between individuals with OSCC from healthy controls and OPMD patients, with AUC of 0.89 and 0.87 respectively [151].

The use of salivary IL- $1 \alpha$, IL- $1 \beta$, and IL-1RA as HNSCC biomarkers is promising, but as there are many local and systemic diseases that can give rise to elevated salivary IL-1 or decreased IL-1RA levels (e.g., periodontal disease, oral lichen planus, Sögren's syndrome) [94, 160, 161], which increases the likelihood of false positives, more clinical studies are needed before translating this into clinical practice.

\section{Therapeutics}

Many beneficial functions of IL-1 inhibition have been described in different cancers, thus, targeting IL-1 has been proposed as a possible therapy for IL-1 expressing tumors, such as melanoma, gastric and breast cancers, among others [162]. In gastric 
cancer, recombinant IL-1RA inhibited tubule formation [163] and reduced proliferation and migration of endothelial cells in vitro in a dose-dependent manner [164]. Similar results have been reported in breast cancer. A murine experimental breast cancer model showed that treatment with anakinra (a recombinant form of IL-1RA with FDA approval for the treatment of rheumatoid arthritis and cryopyrin-associated periodic syndromes) reduced the size and number of bone metastases as well as tumor angiogenesis [165]. Taken together, these data suggest that rIL1RA could be a beneficial alternative for the inhibition of tumordependent angiogenesis, probably by reducing the production of VEGF, CXCL8, endothelin-1, IL-1 $\beta$ and hepatocyte growth factor (HGF) [164-166].

Anakinra has been used in clinical trials for the treatment of some cancers. The first study to use anakinra as a cancer treatment was a phase II clinical trial of pre-multiple myeloma. Anakinra in combination with dexamethasone was found to increase the progression-free survival as well as overall survival in patients at high risk of progressing to multiple myeloma, by targeting the IL-1/IL-6 pathway [167]. In refractory metastatic colorectal cancer, anakinra in combination with fluorouracil (an anti-metabolite) and bevacizumab (anti-EGF monoclonal antibody) showed good efficacy with low toxicity. Currently, there are several clinical trials where recombinant IL-1RA is being tested either as a monotherapy or in combination for the treatment of different cancers, including multiple myeloma, prostate, breast, pancreatic, and colorectal cancers (https:// clinicaltrials.gov/ct $2 /$ results? cond=Cancer\&term =termIL1RA+

$\mathrm{OR}+$ Anakinra\&cntry $=\&$ state $=\&$ city $=\&$ dist $=)$. Nevertheless, care must be taken when considering IL-1RA therapy for HNSCC treatment, as recombinant IL-1RA is likely reduce the innate immunity response in already ill patients, which in theory, could worsens the disease. Thus, IL-1RA replacement therapy may be only appropriate for IL-1 producing tumors [162].

Exogenous IL-1RA (i.e., anakinra) corresponds to the secreted isoform of IL-1RA, which is present in very low levels in oral keratinocytes, as oral keratinocytes constitutively express icIL-1RA1. It is not entirely clear how exogenous IL-1RA works. It is thought that exogenous IL-1RA acts in a similar manner to sIL-1RA, by blocking IL-1R1 on the cell membrane. Nevertheless, exogenous IL-1RA has been shown to be incorporated into the cytoplasm of cardiac myocytes during ischemia, mimicking the intracellular form of IL-1RA, at least in terms of intracellular distribution [168]. Whether exogenous IL-1RA can replace icIL-1RA (which expression is lost during the malignant transformation process of oral keratinocytes and OSCC) functions is not known.

Despite the data supporting an oncogenic role of the IL1/IL-1R1 axis in HNSCC, there is a lack of studies that have

\section{REFERENCES}

1. Kuper H, Adami HO, Trichopoulos D. Infections as a major preventable cause of human cancer. J Intern Med. (2000) 248:171-83. doi: 10.1046/j.1365-2796.2000.00742.x explored the use of IL-1 inhibition for HNSCC treatment. A recent study [115] showed that exogenous IL-1RA can inhibit the growth of Cal27 cells (a tongue squamous adenocarcinoma cell line) in vitro, but more importantly, can potentially interrupt the oral carcinogenesis process in vivo. Submucosal injections of IL-1RA into the tongue of mice during 4NQO-induced oral carcinogenesis interrupted the malignant transformation process. This was done presumably by downregulating genes that were upregulated during the $4 \mathrm{NQO}$-induced carcinogenesis process, such as the oncogene Myc and COX-2 [115]. In addition, anakinra has been shown to overcome erlotinib (an EGFR inhibitor) resistance in a HNSCC mouse xenograft cancer model, suggesting its use as a possible strategy to overcome EGFR inhibitor resistance for HNSCC treatment [169]. Although these initial data are promising, there are no clinical trials that have assessed anakinra for HNSCC treatment and more research in this area is warranted.

\section{CONCLUSION}

There is compelling evidence that the IL-1 signaling pathway is deregulated in HNSCC, with overexpression of agonistic molecules and downregulation of inhibitory factors. This results in a dysregulated signaling pathway that mediates the development of a pro-inflammatory microenvironment prone to tumor development, progression and metastasis. Oral carcinogenesis is a multistep process which includes three phases: initiation, promotion, and progression. The available evidence suggests IL- 1 signaling to influence the promotion and progression phases of the malignant transformation process. The increased presence of IL-1 in HNSCC support the idea that salivary IL-1 could be of use as a screening tool for the early detection of cancer, probably as part of a biomarker panel rather than as a single marker. Early data shows promise, although more rigorous studies are needed before this can be translated into clinical practice. IL-1 inhibition is already being tested as a possible treatment alternative for different cancers, such as myeloma, breast, pancreatic and colorectal cancers, and there are in vivo animal studies showing promising results for HNSCC treatment. However, there is still a long way to go before this can be applied in a clinical setting.

\section{AUTHOR CONTRIBUTIONS}

All three authors contributed equally to the writing of this review. The concept and outline were agreed upon by all. SN wrote the initial draft and constructed the figures. All authors agree on the final version for submission.
2. Apte RN, Dotan S, Elkabets M, White MR, Reich E, Carmi $\mathrm{Y}$, et al. The involvement of IL-1 in tumorigenesis, tumor invasiveness, metastasis and tumor-host interactions. Cancer Metastasis Rev. (2006) 25:387-408. doi: 10.1007/s10555-006-9 004-4 
3. Niklander SE. Inflammatory mediators in oral cancer: pathogenic mechanisms and diagnostic potential. Front Oral Health. (2021) 2. doi: 10.3389/froh.2021.642238

4. Portier M, Zhang XG, Ursule E, Lees D, Jourdan M, Bataille R, et al. Cytokine gene expression in human multiple myeloma. $\mathrm{Br} J$ Haematol. (1993) 85:514-20. doi: 10.1111/j.1365-2141.1993.tb03341.x

5. Voronov E, Dinarello CA, Apte RN. Interleukin-1alpha as an intracellular alarmin in cancer biology. Semin Immunol. (2018) 38:3-14. doi: 10.1016/j.smim.2018.10.006

6. Mantovani A, Barajon I, Garlanda C. IL-1 and IL-1 regulatory pathways in cancer progression and therapy. Immunol Rev. (2018) 281:5761. doi: 10.1111/imr.12614

7. Elaraj DM, Weinreich DM, Varghese S, Puhlmann M, Hewitt $\mathrm{SM}$, Carroll NM, et al. The role of interleukin 1 in growth and metastasis of human cancer xenografts. Clin Cancer Res. (2006) 12:1088-96. doi: 10.1158/1078-0432.CCR-05-1603

8. Rao SK, Pavicevic Z, Du Z, Kim JG, Fan M, Jiao Y, et al. Pro-inflammatory genes as biomarkers and therapeutic targets in oral squamous cell carcinoma. J Biol Chem. (2010) 285:32512-21. doi: 10.1074/jbc.M110.150490

9. Goertzen C, Mahdi H, Laliberte C, Meirson T, Eymael D, Gil-Henn H, et al. Oral inflammation promotes oral squamous cell carcinoma invasion. Oncotarget. (2018) 9:29047-63. doi: 10.18632/oncotarget.25540

10. Al-Sahaf S, Hendawi NB, Ollington B, Bolt R, Ottewell PD, Hunter $\mathrm{KD}$, et al. Increased abundance of tumour-associated neutrophils in hpv-negative compared to HPV-positive oropharyngeal squamous cell carcinoma is mediated by IL-1R Signalling. Front Oral Health. (2021) 2. doi: 10.3389/froh.2021.604565

11. Al-Sahaf S, Hunter KD, Bolt R, Ottewell PD, Murdoch C. The IL-1/IL$1 \mathrm{R}$ axis induces greater fibroblast-derived chemokine release in human papillomavirus-negative compared to positive oropharyngeal cancer. Int $J$ Cancer. (2019) 144:334-44. doi: 10.1002/ijc.31852

12. Alves AM, Diel LF, Lamers ML. Macrophages and prognosis of oral squamous cell carcinoma: A systematic review. J Oral Pathol Med. (2018) 47:460-7. doi: 10.1111/jop.12643

13. Trellakis S, Bruderek K, Dumitru CA, Gholaman H, Gu X, Bankfalvi A, et al. Polymorphonuclear granulocytes in human head and neck cancer: enhanced inflammatory activity, modulation by cancer cells and expansion in advanced disease. Int J Cancer. (2011) 129:2183-93. doi: 10.1002/ijc.25892

14. Ward MJ, Thirdborough SM, Mellows T, Riley C, Harris S, Suchak K, et al. Tumour-infiltrating lymphocytes predict for outcome in HPV-positive oropharyngeal cancer. Br J Cancer. (2014) 110:489-500. doi: 10.1038/bjc.2013.639

15. Garlanda C, Dinarello CA, Mantovani A. The interleukin-1 family: back to the future. Immunity. (2013) 39:1003-18. doi: 10.1016/j.immuni.2013.11.010

16. Dinarello CA. Introduction to the interleukin-1 family of cytokines and receptors: Drivers of innate inflammation and acquired immunity. Immunol Rev. (2018) 281:5-7. doi: 10.1111/imr.12624

17. Mantovani A, Dinarello CA, Molgora M, Garlanda C. Interleukin-1 and related cytokines in the regulation of inflammation and immunity. Immunity. (2019) 50:778-95. doi: 10.1016/j.immuni.2019.03.012

18. Palomo J, Dietrich D, Martin P, Palmer G, Gabay C. The interleukin (IL)-1 cytokine family-Balance between agonists and antagonists in inflammatory diseases. Cytokine. (2015) 76:25-37. doi: 10.1016/j.cyto.2015.06.017

19. Dower SK, Urdal DL. The interleukin-1 receptor. Immunol Today. (1987) 8:46-51. doi: 10.1016/0167-5699(87)90238-6

20. Zheng Y, Humphry M, Maguire JJ, Bennett MR, Clarke MC. Intracellular interleukin-1 receptor 2 binding prevents cleavage and activity of interleukin-1alpha, controlling necrosis-induced sterile inflammation. Immunity. (2013) 38:285-95. doi: 10.1016/j.immuni.2013.01.008

21. Kobayashi Y, Yamamoto K, Saido T, Kawasaki H, Oppenheim JJ, Matsushima K. Identification of calcium-activated neutral protease as a processing enzyme of human interleukin 1 alpha. Proc Natl Acad Sci U S A. (1990) 87:5548-52. doi: 10.1073/pnas.87.14.5548

22. Gayle RB, Poindexter K, Cosman D, Dower SK, Gillis S, Hopp $\mathrm{T}$, et al. Identification of regions in interleukin-1 alpha important for activity. J Biological Chemistry. (1993) 268:2210511. doi: 10.1016/S0021-9258(20)80654-1
23. Labriola-Tompkins E, Chandran C, Varnell TA, Madison VS, Ju G. Structurefunction analysis of human IL-1 alpha: identification of residues required for binding to the human type I IL-1 receptor. Protein Eng. (1993) 6:5359. doi: 10.1093/protein/6.5.535

24. Kim B, Lee Y, Kim E, Kwak A, Ryoo S, Bae SH, et al. The Interleukin-1alpha Precursor is biologically active and is likely a key alarmin in the IL-1 family of cytokines. Front Immunol. (2013) 4:391. doi: 10.3389/fimmu.2013.00391

25. Dinarello CA. Interleukin-1, interleukin-1 receptors and interleukin-1 receptor antagonist. Intern Rev Immunol. (1998) 16:457-99. doi: 10.3109/08830189809043005

26. Dinarello CA, Thompson RC. Blocking IL-I: interleukin I receptor antagonistin vivo andin vitro. Immunol Today. (1991) 12:404-10. doi: 10.1016/0167-5699(91)90142-G

27. Hammerberg C, Arend WP, Fisher GJ, Chan LS, Berger AE, Haskill JS, et al. Interleukin-1 receptor antagonist in normal and psoriatic epidermis. J Clin Invest. (1992) 90:571-83. doi: 10.1172/JCI115896

28. Maier JA, Statuto M, Ragnotti G. Endogenous interleukin 1 alpha must be transported to the nucleus to exert its activity in human endothelial cells. Mol Cell Biol. (1994) 14:1845-51. doi: 10.1128/mcb.14.3.1845-1851.1994

29. Di Paolo NC, Shayakhmetov DM. Interleukin 1alpha and the inflammatory process. Nat Immunol. (2016) 17:906-13. doi: 10.1038/ni.3503

30. Maier JA, Voulalas P, Roeder D, Maciag T. Extension of the life-span of human endothelial cells by an interleukin-1 alpha antisense oligomer. Science (New York, NY). (1990) 249:1570-4. doi: 10.1126/science.2218499

31. Mariotti M, Castiglioni S, Bernardini D, Maier JA. Interleukin 1 alpha is a marker of endothelial cellular senescent. Immunity \& ageing: I \& A. (2006) 3:4. doi: 10.1186/1742-4933-3-4

32. Acosta JC, Banito A, Wuestefeld T, Georgilis A, Janich P, Morton JP, et al. A complex secretory program orchestrated by the inflammasome controls paracrine senescence. Nat Cell Biol. (2013) 15:978-90. doi: 10.1038/ncb2784

33. Corradi A, Franzi AT, Rubartelli A. Synthesis and secretion of interleukin-1 alpha and interleukin-1 receptor antagonist during differentiation of cultured keratinocytes. Exp Cell Res. (1995) 217:355-62. doi: 10.1006/excr.1995.1097

34. Cohen I, Rider P, Vornov E, Tomas M, Tudor C, Wegner M, et al. IL-1alpha is a DNA damage sensor linking genotoxic stress signaling to sterile inflammation and innate immunity. Sci Rep. (2015) 5:14756. doi: 10.1038/srep14756

35. Kawaguchi Y, Hara M, Wright TM. Endogenous IL-1alpha from systemic sclerosis fibroblasts induces IL-6 and PDGF-A. J Clin Invest. (1999) 103:1253-60. doi: 10.1172/JCI4304

36. Wolf JS, Chen Z, Dong G, Sunwoo JB, Bancroft CC, Capo DE, et al. IL (Interleukin)-1 promotes nuclear factor- B and AP-1-induced IL-8 expression, cell survival, and proliferation in head and neck squamous cell carcinomas. Clinical Cancer Research. (2001) 7:1812-20.

37. Orjaloa AV, Bhaumika D, Genglera BK, Scotta GK, Campisi J. Cell surfacebound IL-1 is an upstream regulator of the senescence-associated IL-6/IL-8 cytokine network. PNAS. (2009) 106:17031-6. doi: 10.1073/pnas.0905299106

38. Werman A, Werman-Venkert R, White R, Lee JK, Werman B, Krelin Y, et al. The precursor form of IL-1alpha is an intracrine proinflammatory activator of transcription. Proc Natl Acad Sci U S A. (2004) 101:24349. doi: 10.1073/pnas.0308705101

39. Wessendorf JH, Garfinkel S, Zhan X, Brown S, Maciag T. Identification of a nuclear localization sequence within the structure of the human interleukin-1 alpha precursor. J Biol Chem. (1993) 268:22100-4. doi: 10.1016/S0021-9258(20)80653-X

40. Stevenson FT, Turck J, Locksley RM, Lovett DH. The N-terminal propiece of interleukin 1 is a transforming nuclear oncoprotein. Cell Biology. (1997) 94:508-13. doi: 10.1073/pnas.94.2.508

41. Buryskova M, Pospisek M, Grothey A, Simmet T, Burysek L. Intracellular interleukin-1alpha functionally interacts with histone acetyltransferase complexes. J Biol Chem. (2004) 279:4017-26. doi: 10.1074/jbc.M30634 2200

42. McMahon GA, Garfinkel S, Prudovsky I, Hu X, Maciag T. Intracellular precursor interleukin (IL)- $1 \alpha$, but not mature IL-1 $\alpha$, is able to regulate human endothelial cell migration in vitro. J Biol Chem. (1997) 272:282025. doi: $10.1074 /$ jbc.272.45.28202 
43. Palmer G, Trolliet S, Talabot-Ayer D, Mezin F, Magne D, Gabay C. Preinterleukin-1alpha expression reduces cell growth and increases interleukin6 production in SaOS-2 osteosarcoma cells: Differential inhibitory effect of interleukin-1 receptor antagonist (icIL-1Ra1). Cytokine. (2005) 31:15360. doi: 10.1016/j.cyto.2005.03.007

44. Dinarello CA. Biologic basis for interleukin-1 in disease. Blood. (1996) 87:2095-147. doi: 10.1182/blood.V87.6.2095.bloodjournal8762095

45. Rider P, Carmi Y, Guttman O, Braiman A, Cohen I, Voronov E, et al. IL-1alpha and IL-1beta recruit different myeloid cells and promote different stages of sterile inflammation. J Immunol. (2011) 187:483543. doi: 10.4049/jimmunol.1102048

46. Kostura MJ, Tocci MJ, Limjuco G, Chin J, Cameron P, Hillman $\mathrm{AG}$, et al. Identification of a monocyte specific pre-interleukin 1 beta convertase activity. Proc Natl Acad Sci U S A. (1989) 86:522731. doi: $10.1073 /$ pnas.86.14.5227

47. Joosten LA, Netea MG, Dinarello CA. Interleukin-1beta in innate inflammation, autophagy and immunity. Semin Immunol. (2013) 25:41624. doi: 10.1016/j.smim.2013.10.018

48. Dinarello CA, Ikejima T, Warner SJ, Orencole SF, Lonnemann G, Cannon JG, et al. Interleukin 1 induces interleukin 1. I Induction of circulating interleukin 1 in rabbits in vivo and in human mononuclear cells in vitro. $J$ Immunol. (1987) 139:1902-10.

49. Dinarello CA. Immunological and inflammatory functions of the interleukin-1 family. Annu Rev Immunol. (2009) 27:51950. doi: 10.1146/annurev.immunol.021908.132612

50. Jobling SA, Auron PE, Gurka G, Webb AC, McDonald B, Rosenwasser LJ, et al. Biological activity and receptor binding of human prointerleukin-1 beta and subpeptides. J Biol Chem. (1988) 263:16372-8. doi: 10.1016/S0021-9258(18)37603-8

51. Dinarello CA. Interleukin-1 and interleukin-1 antagonism. Blood. (1991) 77:1627-52. doi: 10.1182/blood.V77.8.1627.bloodjournal7781627

52. Luheshi NM, Rothwell NJ, Brough D. Dual functionality of interleukin-1 family cytokines: implications for anti-interleukin-1 therapy. Br J Pharmacol. (2009) 157:1318-29. doi: 10.1111/j.1476-5381.2009.00331.x

53. Voronov E, Shouval DS, Krelin Y, Cagnano E, Benharroch D, Iwakura Y, et al. IL-1 is required for tumor invasiveness and angiogenesis. Proc Natl Acad Sci US A. (2003) 100:2645-50. doi: 10.1073/pnas.0437939100

54. Niklander S, Bordagaray MJ, Fernández A, Hernández M. Vascular endothelial growth factor: a translational view in oral non-communicable diseases. Biomolecules. (2021) 11:85. doi: 10.3390/biom11010085

55. Rigante D, Frediani B, Cantarini L. A Comprehensive overview of the hereditary periodic fever syndromes. Clinical Rev Allergy Immunol. (2016) 54:446-53. doi: 10.1007/s12016-016-8537-8

56. Cohen J. The immunopathogenesis of sepsis. Nature. (2002) 420:88591. doi: $10.1038 /$ nature 01326

57. Giacomelli R, Ruscitti P, Alvaro S, Ciccia F, Liakouli V, Di Benedetto P, et al. IL-1beta at the crossroad between rheumatoid arthritis and type 2 diabetes: may we kill two birds with one stone? Expert Rev Clin Immunol. (2016) 1-7. doi: 10.1586/1744666X.2016.1168293

58. Kim RY, Pinkerton JW, Gibson PG, Cooper MA, Horvat JC, Hansbro PM. Inflammasomes in COPD and neutrophilic asthma. Thorax. (2015) 70:1199-201. doi: 10.1136/thoraxjnl-2014-206736

59. Mosley B, Urdal DL, Prickett KS, Larsen A, Cosman D, Conlon PJ, et al. The interleukin-1 receptor binds the human interleukin-1 alpha precursor but not the interleukin-1 beta precursor. J Biol Chem. (1987) 262:29414. doi: 10.1016/S0021-9258(18)61450-4

60. Greenfeder SA, Nunes P, Kwee L, Labow M, Chizzonite RA, Ju G. Molecular cloning and characterization of a second subunit of the interleukin 1 receptor complex. J Biol Chem. (1995) 270:13757-65. doi: 10.1074/jbc.270.23.13757

61. Dinarello CA. Overview of the IL-1 family in innate inflammation and acquired immunity. Immunol Rev. (2018) 281:8-27. doi: 10.1111/imr.12621

62. Cullinan EB, Kwee L, Nunes P, Shuster DJ, Ju G, McIntyre KW, et al. IL-1 receptor accessory protein is an essential component of the IL-1 receptor. $J$ Immunol. (1998) 161:5614-20.

63. Gallis B, Prickett KS, Jackson J, Slack J, Schooley K, Sims JE, et al. IL-1 induces rapid phosphorylation of the IL-1 receptor. J Immunol. (1989) 143:3235-40.

64. Weber A, Wasiliew P, Kracht M. Interleukin-1 (IL-1) pathway. Sci Signal. (2010) 3:cm1. doi: 10.1126/scisignal.3105 cm1
65. Niklander SE, Crane HL, Darda L, Lambert DW, Hunter KD. The role of icIL-1RA in keratinocyte senescence and development of the senescenceassociated secretory phenotype. J Cell Sci. (2021) 134. doi: 10.1242/jcs.252080

66. Sun Y, Zhu D, Wang G, Wang D, Zhou H, Liu X, et al. Pro-inflammatory cytokine IL-1 $\beta$ up-regulates CXC chemokine receptor 4 via Notch and ERK signaling pathways in tongue squamous cell carcinoma. PLoS ONE. (2015) 10:e0132677. doi: 10.1371/journal.pone.0132677

67. Colotta F, Dower SK, Sims JE, Mantovani A. The type II 'decoy' receptor: a novel regulatory pathway for interleukin 1. Immunol Today. (1994) 15:5626. doi: 10.1016/0167-5699(94)90217-8

68. Colotta F, Re F, Muzio M, Bertini R, Polentarutti N, Sironi M, et al. Interleukin-1 type II receptor: a decoy target for IL-1 that is regulated by IL-4. Science (New York, NY). (1993) 261:472-5. doi: 10.1126/science.8332913

69. Kuhn PH, Marjaux E, Imhof A, De Strooper B, Haass C, Lichtenthaler SF. Regulated intramembrane proteolysis of the interleukin-1 receptor II by alpha-, beta-, and gamma-secretase. J Biol Chem. (2007) 282:1198295. doi: 10.1074/jbc.M700356200

70. Arend WP, Joslin FG, Thompson RC, Hannum CH. An IL-1 inhibitor from human monocytes. Production and characterization of biologic properties. $J$ Immunol. (1989) 143:1851-8.

71. Kurzrock R, Hickish T, Wyrwicz L, Saunders M, Wu Q, Stecher M, et al. Interleukin-1 receptor antagonist levels predict favorable outcome after bermekimab, a first-in-class true human interleukin-1alpha antibody, in a phase III randomized study of advanced colorectal cancer. Oncoimmunology. (2019) 8:1551651. doi: 10.1080/2162402X.2018.1551651

72. Hannum CH, Wilcox CJ, Arend WP, Joslin FG, Dripps DJ, Heimdal PL, et al. Interleukin-1 receptor antagonist activity of a human interleukin-1 inhibitor. Nature. (1990) 343:336-43. doi: 10.1038/343336a0

73. Arend WP, Welgus HG, Thompson RC, Eisenberg SP. Biological properties of recombinant human monocyte-derived interleukin 1 receptor antagonist. J Clin Invest. (1990) 85:1694-7. doi: 10.1172/JCI114622

74. Arend WP, Joslin FG, Massoni RJ. Effects of immune complexes on production by human monocytes of interleukin 1 or an interleukin 1 inhibitor. J Immunol. (1985) 134:3868-75.

75. Haskill S, Martin G, Van Le L, Morris J, Peace A, Bigler CF, et al. cDNA cloning of an intracellular form of the human interleukin 1 receptor antagonist associated with epithelium. Cell Biology. (1991) 88:36815. doi: 10.1073/pnas.88.9.3681

76. Muzio M, Polentarutti N, Sironi M, Poli G, De Gioia L, Introna M, et al. Cloning and characterization of a new isoform of the interleukin 1 receptor antagonist. J Exp Med. (1995) 182:623-8. doi: 10.1084/jem.182.2.623

77. Malyak M, Guthridge JM, Hance KR, Dower SK, Freed JH, Arend WP. Characterization of a low molecular weight isoform of IL-1 receptor antagonist. J Immunol. (1998) 161:1997-2003.

78. Malyak M, Smith MF, Abel AA, Hance KR, Arend WP. The differential production of three forms of IL-1 receptor antagonist by human neutrophils and monocytes. J Immunol. (1998) 161:2004-10.

79. La E, Rundhaug JE, Fischer SM. Role of intracellular interleukin-1 receptor antagonist in skin carcinogenesis. Mol Carcinog. (2001) 30:21823. doi: $10.1002 / \mathrm{mc} .1031$

80. Shiiba M, Saito K, Yamagami H, Nakashima D, Higo M, Kasamatsu A, et al. Interleukin-1 receptor antagonist (IL1RN) is associated with suppression of early carcinogenic events in human oral malignancies. Int J Oncol. (2015) 46:1978-84. doi: 10.3892/ijo.2015.2917

81. Lee JK, Kim SH, Lewis EC, Azam T, Reznikov LL, Dinarello CA. Differences in signaling pathways by IL-1beta and IL-18. Proc Natl Acad Sci U S A. (2004) 101:8815-20. doi: 10.1073/pnas.04028 00101

82. Naik SM, Cannon G, Burbach GJ, Singh SR, Swerlick RA, Wilcox $\mathrm{JN}$, et al. Human keratinocytes constitutively express interleukin18 and secrete biologically active interleukin-18 after treatment with pro-inflammatory mediators and dinitrochlorobenzene. J Invest Dermatol. (1999) 113:766-72. doi: 10.1046/j.1523-1747.1999.0 0750.x

83. Carriere V, Roussel L, Ortega N, Lacorre DA, Americh L, Aguilar L, et al. IL-33, the IL-1-like cytokine ligand for ST2 receptor, is a chromatinassociated nuclear factor in vivo. Proc Natl Acad Sci U S A. (2007) 104:2827. doi: 10.1073/pnas.0606854104 
84. Onoufriadis A, Simpson MA, Pink AE, Di Meglio P, Smith CH, Pullabhatla $\mathrm{V}$, et al. Mutations in IL36RN/IL1F5 are associated with the severe episodic inflammatory skin disease known as generalized pustular psoriasis. Am J Hum Genet. (2011) 89:432-7. doi: 10.1016/j.ajhg.2011.07.022

85. Mora J, Schlemmer A, Wittig I, Richter F, Putyrski M, Frank $\mathrm{AC}$, et al. Interleukin-38 is released from apoptotic cells to limit inflammatory macrophage responses. J Mol Cell Biol. (2016) 8:426-38. doi: 10.1093/jmcb/mjw006

86. Boutet MA, Najm A, Bart G, Brion R, Touchais S, Trichet V, et al. IL-38 overexpression induces anti-inflammatory effects in mice arthritis models and in human macrophages in vitro. Ann Rheum Dis. (2017) 76:130412. doi: 10.1136/annrheumdis-2016-210630

87. Perrier S, Kherratia B, Deschaumes C, Ughetto S, Kemeny L. IL-1ra and IL1 production in human oral mucosal epithelial cells in culture: differential modulation by TGF- 1 and IL-4. Clin Exp Immunol. (2002) 127:539. doi: 10.1046/j.1365-2249.2002.01685.x

88. Mizutani H, Black R, Kupper TS. Human keratinocytes produce but do not process pro-interleukin-1 (IL-1) beta. Different strategies of IL-1 production and processing in monocytes and keratinocytes. J Clin Invest. (1991) 87:1066-71. doi: 10.1172/JCI115067

89. Garat C, Arend WP. Intracellular IL-1Ra type 1 inhibits IL-1-induced IL-6 and IL-8 production in Caco-2 intestinal epithelial cells through inhibition of p38 mitogen-activated protein kinase and NF-kappaB pathways. Cytokine. (2003) 23:31-40. doi: 10.1016/S1043-4666(03)00182-0

90. Phillips WG, Feldmann M, Breathnach SM, Brennan FM. Modulation of the IL-1 cytokine network in keratinocytes by intracellular ILla and IL-1 receptor antagonist. Clin Exp Immunol. (1995) 101:17782. doi: 10.1111/j.1365-2249.1995.tb02295.x

91. Banda NK, Guthridge C, Sheppard D, Cairns KS, Muggli M, BechOtschir D, et al. Intracellular IL-1 receptor antagonist type 1 inhibits IL1-induced cytokine production in keratinocytes through binding to the third component of the COP9 signalosome. J Immunol. (2005) 174:360816. doi: 10.4049/jimmunol.174.6.3608

92. Groves RW, Giri J, Sims J, Dower SK, Kupper TS. Inducible expression of type 2 IL-1 receptors by cultured human keratinocytes. Implications for IL-1-mediated processes in epidermis. J Immunol. (1995) 154:4065-72.

93. Kondo M, Yamato M, Takagi R, Namiki H, Okano T. The regulation of epithelial cell proliferation and growth by IL-1 receptor antagonist. Biomaterials. (2013) 34:121-9. doi: 10.1016/j.biomaterials.2012.09.036

94. Dubost JJ, Perrier S, Afane M, Viallard JL, Roux-Lombard P, Baudet-Pommel $\mathrm{M}$, et al. IL-1 receptor antagonist in saliva; characterization in normal saliva and reduced concentration in Sjogren's syndrome (SS). Clin Exp Immunol. (1996) 106:237-42. doi: 10.1046/j.1365-2249.1996.d01-824.x

95. Sharpless NE, Sherr CJ. Forging a signature of in vivo senescence. Nat Rev Cancer. (2015) 15:397-408. doi: 10.1038/nrc3960

96. Davalos AR, Coppe JP, Campisi J, Desprez PY. Senescent cells as a source of inflammatory factors for tumor progression. Cancer Metastasis Rev. (2010) 29:273-83. doi: 10.1007/s10555-010-9220-9

97. Woods RV, Adler-Storthz K, Dayman GL, Francis GM, Grimm EA. Interleukin-1 regulates interleukin-6 secretion in human oral squamous cell carcinoma in vitro: possible influence of p53 but not human papillomavirus E6/E. Cancer Res. (1998) 58:3142-9.

98. Lee CH, Chang JS, Syu SH, Wong TS, Chan JY, Tang YC, et al. IL-1beta promotes malignant transformation and tumor aggressiveness in oral cancer. J Cell Physiol. (2015) 230:875-84. doi: 10.1002/jcp. 24816

99. von Biberstein SE, Spiro JD, Lindquist R, Kreutzer DL. Interleukin-1 receptor antagonist in head and neck squamous cell carcinoma. Arch Otolaryngol Head Neck Surg. (1996) 122:751-9. doi: 10.1001/archotol.1996.0189019004 7012

100. Leon X, Bothe C, Garcia J, Parreno M, Alcolea S, Quer M, et al. Expression of IL-1alpha correlates with distant metastasis in patients with head and neck squamous cell carcinoma. Oncotarget. (2015) 6:37398409. doi: 10.18632/oncotarget.6054

101. Coppe JP, Patil CK, Rodier F, Sun Y, Munoz DP, Goldstein J, et al. Senescenceassociated secretory phenotypes reveal cell-nonautonomous functions of oncogenic RAS and the p53 tumor suppressor. PLoS Biol. (2008) 6:285368. doi: 10.1371/journal.pbio.0060301
102. Sparmann A, Bar-Sagi D. Ras-induced interleukin-8 expression plays a critical role in tumor growth and angiogenesis. Cancer Cell. (2004) 6:44758. doi: 10.1016/j.ccr.2004.09.028

103. Ancrile B, Lim KH, Counter CM. Oncogenic Ras-induced secretion of IL6 is required for tumorigenesis. Genes Dev. (2007) 21:17149. doi: $10.1101 / \mathrm{gad} .1549407$

104. Loaiza N, Demaria M. Cellular senescence and tumor promotion: Is aging the key? Biochim Biophys Acta. (2016) 1865:15567. doi: 10.1016/j.bbcan.2016.01.007

105. Yang X, Cheng H, Chen J, Wang R, Saleh A, Si H, et al. Head and neck cancers promote an inflammatory transcriptome through coactivation of classic and alternative NF-кB pathways. Cancer Immunol Res. (2019) 7:176074. doi: 10.1158/2326-6066.CIR-18-0832

106. Zhang J, Peng B. NF-kappaB promotes iNOS and VEGF expression in salivary gland adenoid cystic carcinoma cells and enhances endothelial cell motility in vitro. Cell Prolif. (2009) 42:150-61. doi: 10.1111/j.1365-2184.2009.00588.x

107. Julien S, Puig I, Caretti E, Bonaventure J, Nelles L, van Roy F, et al. Activation of NF-kappaB by Akt upregulates Snail expression and induces epithelium mesenchyme transition. Oncogene. (2007) 26:744556. doi: 10.1038/sj.onc. 1210546

108. Nakayama H, Ikebe T, Beppu M, Shirasuna K. High expression levels of nuclear factor kappaB, IkappaB kinase alpha and Akt kinase in squamous cell carcinoma of the oral cavity. Cancer. (2001) 92:303744. doi: 10.1002/1097-0142(20011215)92:12<3037::AID-CNCR10171> 3.0.CO;2-\%23

109. Jimi E, Kokabu S, Matsubara T, Nakatomi C, Matsuo K, Watanabe S. NF- $\kappa$ B acts as a multifunctional modulator in bone invasion by oral squamous cell carcinoma. Oral Science International. (2016) 13:16. doi: 10.1016/S1348-8643(15)00038-5

110. Tanaka T, Nakayama H, Yoshitake Y, Irie A, Nagata M, Kawahara K, et al. Selective inhibition of nuclear factor- $\kappa \mathrm{B}$ by nuclear factor- $\kappa \mathrm{B}$ essential modulator-binding domain peptide suppresses the metastasis of highly metastatic oral squamous cell carcinoma. Cancer Sci. (2012) 103:45563. doi: 10.1111/j.1349-7006.2011.02174.x

111. Duffey DC, Chen Z, Dong G, Ondrey FG, Wolf JS, Brown K, et al. Expression of a dominant-negative mutant inhibitor-kappaBalpha of nuclear factorkappaB in human head and neck squamous cell carcinoma inhibits survival, proinflammatory cytokine expression, and tumor growth in vivo. Cancer Res. (1999) 59:3468-74.

112. Wu D, Wu P, Zhao L, Huang L, Zhang Z, Zhao S, et al. NF-кB Expression and outcomes in solid tumors: A systematic review and meta-analysis. Medicine (Baltimore). (2015) 94:e1687. doi: 10.1097/MD.0000000000001687

113. Alam M, Kashyap T, Pramanik KK, Singh AK, Nagini S, Mishra R. The elevated activation of NFKB and AP-1 is correlated with differential regulation of $\mathrm{Bcl}-2$ and associated with oral squamous cell carcinoma progression and resistance. Clin Oral Investig. (2017) 21:272131. doi: 10.1007/s00784-017-2074-6

114. Lakhanpal M, Yadav DS, Devi TR, Singh LC, Singh KJ, Latha SP, et al. Association of interleukin-1beta-511 C/T polymorphism with tobaccoassociated cancer in northeast India: a study on oral and gastric cancer. Cancer Genet. (2014) 207:1-11. doi: 10.1016/j.cancergen.2014.01.002

115. Wu T, Hong Y, Jia L, Wu J, Xia J, Wang J, et al. Modulation of IL-1beta reprogrammes the tumor microenvironment to interrupt oral carcinogenesis. Sci Rep. (2016) 6:20208. doi: 10.1038/srep20208

116. Hazuda DJ, Strickler J, Kueppers F, Simon PL, Young PR. Processing of precursor interleukin 1 beta and inflammatory disease. J Biol Chem. (1990) 265:6318-22. doi: 10.1016/S0021-9258(19)39328-7

117. He KF, Zhang L, Huang CF, Ma SR, Wang YF, Wang WM, et al. CD163+ tumor-associated macrophages correlated with poor prognosis and cancer stem cells in oral squamous cell carcinoma. Biomed Res Int. (2014) 2014:838632. doi: 10.1155/2014/838632

118. Bae JY, Kim EK, Yang DH, Zhang X, Park YJ, Lee DY, et al. Reciprocal interaction between carcinoma-associated fibroblasts and squamous carcinoma cells through interleukin-1alpha induces cancer progression. Neoplasia. (2014) 16:928-38. doi: 10.1016/j.neo.2014.09.003

119. Huang YH, Chang CY, Kuo YZ, Fang WY, Kao HY, Tsai ST, et al. Cancerassociated fibroblast-derived interleukin-1 $\beta$ activates protumor C-C motif 
chemokine ligand 22 signaling in head and neck cancer. Cancer Sci. (2019) 110:2783-93. doi: $10.1111 /$ cas.14135

120. Liss C, Fekete MJ, Hasina R, Lam CD, Lingen MW. Paracrine angiogenic loop between head-and-neck squamous-cell carcinomas and macrophages. Int J Cancer. (2001) 93:781-5. doi: 10.1002/ijc.1407

121. Hakelius M, Koskela A, Reyhani V, Ivarsson M, Grenman R, Rubin $\mathrm{K}$, et al. Interleukin-1-mediated effects of normal oral keratinocytes and head and neck squamous carcinoma cells on extracellular matrix related gene expression in fibroblasts. Oral Oncol. (2012) 48:123641. doi: 10.1016/j.oraloncology.2012.06.013

122. Glogauer JE, Sun CX, Bradley G, Magalhaes MA. Neutrophils Increase Oral Squamous Cell Carcinoma Invasion through an Invadopodia-Dependent Pathway. Cancer Immunol Res. (2015) 3:1218-26. doi: 10.1158/2326-6066.CIR-15-0017

123. Wei LY, Lee JJ, Yeh CY, Yang CJ, Kok SH, Ko JY, et al. Reciprocal activation of cancer-associated fibroblasts and oral squamous carcinoma cells through CXCL1. Oral Oncol. (2019) 88:115-23. doi: 10.1016/j.oraloncology.2018.11.002

124. Alcolea S, Antón R, Camacho M, Soler M, Alfranca A, Avilés-Jurado FX, et al. Interaction between head and neck squamous cell carcinoma cells and fibroblasts in the biosynthesis of PGE2. J Lipid Res. (2012) 53:63042. doi: 10.1194/jlr.M019695

125. Morita Y, Morita N, Hata K, Nakanishi M, Kimoto N, Omata T, et al. Cyclooxygenase-2 expression is associated with vascular endothelial growth factor-c and lymph node metastasis in human oral tongue cancer. Oral Surg Oral Med Oral Pathol Oral Radiol. (2014) 117:50210. doi: 10.1016/j.oooo.2013.12.410

126. St John MA, Dohadwala M, Luo J, Wang G, Lee G, Shih $\mathrm{H}$, et al. Proinflammatory mediators upregulate snail in head and neck squamous cell carcinoma. Clin Cancer Res. (2009) 15:6018-27. doi: 10.1158/1078-0432.CCR-09-0011

127. Yang B, Jia L, Guo Q, Ren H, Hu Y, Xie T. Clinicopathological and prognostic significance of cyclooxygenase-2 expression in head and neck cancer: A meta-analysis. Oncotarget. (2016) 7:47265-77. doi: 10.18632/oncotarget.10059

128. Lee MK, Park JH, Gi SH, Hwang YS. IL-1 $\beta$ Induces Fascin Expression and Increases Cancer Invasion. Anticancer Res. (2018) 38:6127-32. doi: 10.21873/anticanres.12964

129. Dong GW, Do NY, Lim SC. Relation between proinflammatory mediators and epithelial-mesenchymal transition in head and neck squamous cell carcinoma. Exp Ther Med. (2010) 1:885-91. doi: 10.3892/etm.20 10.124

130. St John MA. Inflammatory mediators drive metastasis and drug resistance in head and neck squamous cell carcinoma. Laryngoscope. (2015) $125 \mathrm{Suppl}$ 3:S1-11. doi: 10.1002/lary.24998

131. Lee CH, Wong TS, Chan JY, Lu SC, Lin P, Cheng AJ, et al. Epigenetic regulation of the X-linked tumour suppressors BEX1 and LDOC1 in oral squamous cell carcinoma. J Pathol. (2013) 230:298309. doi: 10.1002/path.4173

132. Alevizos I, Mahadevappa M, Zhang X, Ohyama H, Kohno Y, Posner $\mathrm{M}$, et al. Oral cancer in vivo gene expression profiling assisted by laser capture microdissection and microarray analysis. Oncogene. (2001) 20:6196204. doi: 10.1038/sj.onc. 1204685

133. Choi P, Chen C. Genetic expression profiles and biologic pathway alterations in head and neck squamous cell carcinoma. Cancer. (2005) 104:111328. doi: $10.1002 /$ cncr.21293

134. Cromer A, Carles A, Millon R, Ganguli G, Chalmel F, Lemaire F, et al. Identification of genes associated with tumorigenesis and metastatic potential of hypopharyngeal cancer by microarray analysis. Oncogene. (2004) 23:2484-98. doi: 10.1038/sj.onc. 1207345

135. Leethanakul C, Patel V, Gillespie J, Shillitoe E, Kellman RM, Ensley JF, et al. Gene expression profiles in squamous cell carcinomas of the oral cavity: use of laser capture microdissection for the construction and analysis of stage-specific cDNA libraries. Oral Oncol. (2000) 36:47483. doi: 10.1016/S1368-8375(00)00039-7

136. Schmalbach CE, Chepeha DB, Giordano TJ, Rubin MA, Teknos TN, Bradford CR, et al. Molecular profiling and the identification of genes associated with metastatic oral cavity/pharynx squamous cell carcinoma. Arch Otolaryngol Head Neck Surg. (2004) 130:295-302. doi: 10.1001/archotol.130.3.295

137. Whipple ME, Mendez E, Farwell DG, Agoff SN, Chen C. A genomic predictor of oral squamous cell carcinoma. Laryngoscope. (2004) 114:134654. doi: 10.1097/00005537-200408000-00006

138. Lallemant B, Evrard A, Combescure C, Chapuis H, Chambon G, Raynal C, et al. Clinical relevance of nine transcriptional molecular markers for the diagnosis of head and neck squamous cell carcinoma in tissue and saliva rinse. BMC Cancer. (2009) 9:370. doi: 10.1186/1471-2407-9-370

139. Koike H, Uzawa K, Nakashima D, Shimada K, Kato Y, Higo M, et al. Identification of differentially expressed proteins in oral squamous cell carcinoma using a global proteomic approach. Int J Oncol. (2005) 27:5967. doi: 10.3892/ijo.27.1.59

140. Böcker U, Damiao A, Holt L, Soo Han D, Jobin C, Panja A, et al. Differential expression of interleukin 1 receptor antagonist isoforms in human intestinal epithelial cells. Gastroenterology. (1998) 115:142638. doi: 10.1016/S0016-5085(98)70021-6

141. Bates AM, Gomez Hernandez MP, Lanzel EA, Qian F, Brogden KA. Matrix metalloproteinase (MMP) and immunosuppressive biomarker profiles of seven head and neck squamous cell carcinoma (HNSCC) cell lines. Transl Cancer Res. (2018) 7:533-42. doi: 10.21037/tcr.2018.05.09

142. Tsai MS, Chen WC, Lu CH, Chen MF. The prognosis of head and neck squamous cell carcinoma related to immunosuppressive tumor microenvironment regulated by IL-6 signaling. Oral Oncol. (2019) 91:4755. doi: 10.1016/j.oraloncology.2019.02.027

143. Gaba FI, Sheth CC, Veses V. Salivary biomarkers and their efficacies as diagnostic tools for Oral Squamous Cell Carcinoma: Systematic review and meta-analysis. J Oral Pathol Med. (2018) 50:299-307. doi: 10.1111/jop.12791

144. Rajan A, Gibson-Corley KN, Choi AB, Ofori-Amanfo GK, Ten Eyck P, Espinosa-Cotton M, et al. Impact of nuclear interleukin-1 alpha and EGFR expression on recurrence and survival outcomes in oral squamous cell carcinomas. J Oncol. (2019) 2019:5859680. doi: 10.1155/2019/5859680

145. Iizuka N, Hazama $\mathrm{S}$, Hirose $\mathrm{K}$, Abe $\mathrm{T}$, Tokuda $\mathrm{N}$, Fukumoto $\mathrm{T}$, et al. Interleukin-1 receptor antagonist mRNA expression and the progression of gastric carcinoma. Cancer Lett. (1999) 179-84. doi: 10.1016/S0304-3835(99)00162-7

146. Fujiwaki R, Iida K, Nakayama K, Kanasaki H, Hata K, Katabuchi $\mathrm{H}$, et al. Clinical significance of interleukin-1 receptor antagonist in patients with cervical carcinoma. Gynecol Oncol. (2003) 89:7783. doi: 10.1016/S0090-8258(02)00154-3

147. Tian Y, Sun Y, Wu J, Xiong Z, Niu F, Li H, et al. Impact of IL1R1 polymorphisms on the risk of head and neck cancer in Chinese Han population. Gene. (2020) 757:144927. doi: 10.1016/j.gene.2020.144927

148. Bonne NJ, Wong DT. Salivary biomarker development using genomic, proteomic and metabolomic approaches. Genome Med. (2012) 4:82. doi: $10.1186 / \mathrm{gm} 383$

149. SahebJamee M, Eslami M, AtarbashiMoghadam F, Sarafnejad A. Salivary concentration of TNF $\alpha$, IL1 $\alpha$, IL6, and IL8 in oral squamous cell carcinoma. Med Oral Patol Oral Cir Bucal. (2008) 13:E292-5.

150. Kamatani T, Shiogama S, Yoshihama Y, Kondo S, Shirota T, Shintani S. Interleukin-1 beta in unstimulated whole saliva is a potential biomarker for oral squamous cell carcinoma. Cytokine. (2013) 64:497502. doi: 10.1016/j.cyto.2013.08.011

151. Shan J, Sun Z, Yang J, Xu J, Shi W, Wu Y, et al. Discovery and preclinical validation of proteomic biomarkers in saliva for early detection of oral squamous cell carcinomas. Oral Dis. (2019) 25:97107. doi: 10.1111/odi.12971

152. Brailo V, Vucicevic-Boras V, Lukac J, Biocina-Lukenda D, Zilic-Alajbeg I, Milenovic A, et al. Salivary and serum interleukin 1 beta, interleukin 6 and tumor necrosis factor alpha in patients with leukoplakia and oral cancer. Med Oral Patol Oral Cir Bucal. (2012) 17:e10-5. doi: 10.4317/medoral. 17323

153. Arellano-Garcia ME, Hu S, Wang J, Henson B, Zhou H, Chia $\mathrm{D}$, et al. Multiplexed immunobead-based assay for detection of oral cancer protein biomarkers in saliva. Oral Dis. (2008) 14:705-12. doi: 10.1111/j.1601-0825.2008.01488.x

154. Lee LT, Wong YK, Hsiao HY, Wang YW, Chan MY, Chang KW. Evaluation of saliva and plasma cytokine biomarkers in patients with 
oral squamous cell carcinoma. Int J Oral Maxillofac Surg. (2018) 47:699707. doi: $10.1016 /$ j.ijom.2017.09.016

155. Singh P, Verma JK, Singh JK. Validation of salivary markers, IL-1 $\beta$, IL-8 and Lgals3bp for detection of oral squamous cell carcinoma in an Indian population. Sci Rep. (2020) 10:7365. doi: 10.1038/s41598-020-64494-3

156. Brinkmann O, Kastratovic DA, Dimitrijevic MV, Konstantinovic VS, Jelovac DB, Antic J, et al. Oral squamous cell carcinoma detection by salivary biomarkers in a Serbian population. Oral Oncol. (2011) 47:515. doi: 10.1016/j.oraloncology.2010.10.009

157. Val M, Sidoti Pinto GA, Manini L, Gandolfo S, Pentenero M. Variations of salivary concentration of cytokines and chemokines in presence of oral squamous cell carcinoma. A case-crossover longitudinal prospective study. Cytokine. (2019) 120:62-5. doi: 10.1016/j.cyto.2019.04.009

158. Korostoff A, Reder L, Masood R, Sinha UK. The role of salivary cytokine biomarkers in tongue cancer invasion and mortality. Oral Oncol. (2011) 47:282-7. doi: 10.1016/j.oraloncology.2011.02.006

159. Boldrup L, Coates P, Gu X, Wang L, Fåhraeus R, Wilms T., et al. Low potential of circulating interleukin 1 receptor antagonist as a prediction marker for squamous cell carcinoma of the head and neck. J Oral Pathol Med. (2021) doi: 10.1111/jop.13187

160. Tobón-Arroyave SI, Jaramillo-González PE, Isaza-Guzmán DM. Correlation between salivary IL-1beta levels and periodontal clinical status. Arch Oral Biol. (2008) 53:346-52. doi: 10.1016/j.archoralbio.2007.11.005

161. Rhodus NL, Cheng B, Bowles W, Myers S, Miller L, Ondrey F. Proinflammatory cytokine levels in saliva before and after treatment of (erosive) oral lichen planus with dexamethasone. Oral Dis. (2006) 12:112-6. doi: 10.1111/j.1601-0825.2005.0 1165.x

162. Dinarello CA. Why not treat human cancer with interleukin-1 blockade? Cancer Metastasis Rev. (2010) 29:317-29. doi: 10.1007/s10555-010-9229-0

163. La E, Fischer SM. Transcriptional regulation of intracellular IL-1 receptor antagonist gene by IL-1 in primary mouse keratinocytes. $J$ Immunol. (2001) 166:6149-55. doi: 10.4049/jimmunol.166.10. 6149

164. Gong Z, Ma J, Su H, Guo T, Cai H, Chen Q, et al. Interleukin1 receptor antagonist inhibits angiogenesis in gastric cancer. Int J Clin Oncol. (2018) 23:659-70. doi: 10.1007/s10147-018-1 $242-2$
165. Holen I, Lefley DV, Francis SE, Rennicks S, Bradbury S, Coleman RE, et al. IL-1 drives breast cancer growth and bone metastasis in vivo, Oncotarget. (2016) 7:75571-84. doi: 10.18632/oncotarget.12289

166. Ma J, Sun X, Guo T, Su H, Chen Q, Gong Z, et al. Interleukin-1 receptor antagonist inhibits angiogenesis via blockage IL-1alpha/PI3K/NF-kappabeta pathway in human colon cancer cell. Cancer Manag Res. (2017) 9:48193. doi: 10.2147/CMAR.S147699

167. Lust JA, Lacy MQ, Zeldenrust SR, Witzig TE, Moon-Tasson LL, Dinarello $\mathrm{CA}$, et al. Reduction in C-reactive protein indicates successful targeting of the IL-1/IL-6 axis resulting in improved survival in early stage multiple myeloma. Am J Hematol. (2016) 91:571-4. doi: 10.1002/ajh.24352

168. Abbate A, Salloum FN, Vecile E, Das A, Hoke NN, Straino S, et al. Anakinra, a recombinant human interleukin-1 receptor antagonist, inhibits apoptosis in experimental acute myocardial infarction. Circulation. (2008) 117:267083. doi: 10.1161/CIRCULATIONAHA.107.740233

169. Stanam A, Gibson-Corley KN, Love-Homan L, Ihejirika N, Simons AL. Interleukin-1 blockade overcomes erlotinib resistance in head and neck squamous cell carcinoma. Oncotarget. (2016) 7:76087-100. doi: 10.18632/oncotarget.12590

Conflict of Interest: The authors declare that the research was conducted in the absence of any commercial or financial relationships that could be construed as a potential conflict of interest.

Publisher's Note: All claims expressed in this article are solely those of the authors and do not necessarily represent those of their affiliated organizations, or those of the publisher, the editors and the reviewers. Any product that may be evaluated in this article, or claim that may be made by its manufacturer, is not guaranteed or endorsed by the publisher.

Copyright $\odot 2021$ Niklander, Murdoch and Hunter. This is an open-access article distributed under the terms of the Creative Commons Attribution License (CC BY). The use, distribution or reproduction in other forums is permitted, provided the original author(s) and the copyright owner(s) are credited and that the original publication in this journal is cited, in accordance with accepted academic practice. No use, distribution or reproduction is permitted which does not comply with these terms. 